\title{
Precerebellin-related genes and precerebellin 1 peptide in endocrine glands of the rat - pattern of their expression
}

\author{
MARCIN RUCINSKI and LUDWIK K. MALENDOWICZ
}

Department of Histology and Embryology, Unversity of Medical Sciences, Poznan, PL-60781, Poland

Received August 1, 2008; Accepted October 2, 2008

DOI: 10.3892/ijmm_00000108

\begin{abstract}
The hexadecapeptide cerebellin (CER) is derived from a larger protein, cerebellin 1 precursor protein (Cbln1). At present four precerebellins (Cbln1-4) are known. They are highly expressed in the brain, in particular in the cerebellum. Since CER is involved in regulating endocrine functions, present studies aimed to investigate, by means of molecular biology techniques (RT-PCR, QPCR, Western blotting) the expression of Cbln related genes and Cbln1 protein in classic endocrine glands of the rat. RT-PCR revealed the presence of Cbln 1 and Cbln 3 mRNAs in all endocrine glands tested; hypothalamus, anterior pituitary, thyroid, adrenal cortex, testis, ovary and pancreatic islets. Expression of Cbln2 gene was demonstrated only in the hypothalamus, anterior pituitary and adrenal cortex and in cerebral cortex, which was studied as a positive control organ. On the contrary, expression of Cbln4 gene was found only in the cerebral cortex. Using QPCR, the highest expression of Cbln1 gene was demonstrated in hypothalamus and pancreatic islets, a somewhat lower one in the anterior pituitary and thyroid, while the lowest was in adrenal cortex, testis and ovary. In general, the Cbln3 gene exhibited a similar pattern of expression, with the highest level in pancreatic islets and somewhat lower in the hypothalamus. Cbln 2 gene expression was high in the hypothalamus, lower in the anterior pituitary and very low in adrenal cortex. In general, the pattern of Cbln 1 protein expression was similar to that of Cbln 1 mRNA. Further experiments aimed to check possible association of Cbln1 with cell membrane. Such association is suggested by differences in Cbln 1 protein amount after extraction with RIPA and TRIS buffers. Bioinformatic methods predicting transmembrane topology (HMMTOP and SPLIT 4.0 servers) suggest transmembrane localisation of
\end{abstract}

Correspondence to: Professor Ludwik K. Malendowicz, Department of Histology and Embryology, Poznan University of Medical Sciences, 6 Swiecicki St., 60-781 Poznan, Poland E-mail: 1km@amp.edu.pl

Abbreviations: Cbln, precerebellins; Cbln1-4, precerebellin 1-4; CER, cerebellin; desCER, des-Ser1-cerebellin

Key words: cerebellin, precerebellins, pituitary, thyroid, adrenal, testis, ovary, pancreas, real time PCR, protein expression
Cbln1, with transmembrane domain sequence responsible for the formation of an $\alpha$-helix. These findings suggest possible physiological roles of Cbln related peptides not only in the cerebellum, but also in the endocrine system. However, their specific role as modulators of the endocrine system requires further investigations.

\section{Introduction}

In 1984 Slemmon et al (1) isolated two polypeptides from the rat cerebellum. One of the identified hexadecapeptides was named cerebellin (CER) while its $\mathrm{N}$-terminal truncated version, des-Ser1-cerebellin, was termed des-cerebellin (desCER). It was generally assumed that desCER was an apparent metabolite of CER, the formation of which is catalysed by serine aminopeptidase (1-3). CER is derived from a larger precursor called precerebellin1 (Cbln1). At present four precerebellins are known. Cbln1 is homologous to the originally described human precerebellin (4) while Cbln2 is homologous to rat and murine cerebellin-like proteins identified by Wada and Ohtani (5) and Kavety et al (6). Cbln3 binds specifically to Cbln1 (7) while Cbln 4 has been identified in the mouse (NCBI accession number NM_175631), and recently in human (NM_080617). Precerebellin genes are located at different chromosomes and their related proteins are highly conserved $(6,8,9)$. Previous findings suggest that Cbln 4 may be the prototype of the Cbln subfamily. The entire subfamily of Cbln demonstrates high homology to the family of atypical solluble collagens (types VII and $\mathrm{X})(10,11)$ as well as to $\mathrm{A}, \mathrm{B}$ and $\mathrm{C}$ subunits of the component complex $\mathrm{C} 1 \mathrm{q}$ $(12,13)$. Thus, Cblns belong to the C1q/TNF superfamily of secreted proteins, which suggests that they are biologically active molecules. At least $3 \mathrm{Cbln}$ are secreted from the cells (14). In vitro, all Cblns form not only homomeric but also heteromeric complexes with each other, and regulate synapse development and synaptic plasticity (9). It remains to be established whether this transneuronal regulatory function is also related to CER that may be liberated in the extracellular compartment from Cbln1. Until now neither CER nor Cblns receptors were identified. However, it has been suggested that Cblns complexes may interact with a membrane receptor(s) and activate intracellular transduction cascades (8).

In the CNS expression of Cbln 1 and Cbln 2 is widespread while that of Cbln3 and Cbln 4 is restricted to cerebellar granular cells and certain thalamic nuclei $(7,15)$. Cblns and CER are also present in the extra-cerebral tissues and recent 
Table I. QPCR analysis of precerebellins (Cbln1-4) mRNAs.

\begin{tabular}{|c|c|c|c|c|c|}
\hline cDNA & $\begin{array}{c}\text { Genbank } \\
\text { accession no. }\end{array}$ & Primers & Primer sequence $\left(5^{\prime}-3^{\prime}\right)$ & Position & $\begin{array}{c}\text { PCR } \\
\text { product size (bp) }\end{array}$ \\
\hline Cbln 1 & $\begin{array}{c}\text { XM } \\
001067551\end{array}$ & $\begin{array}{c}\mathrm{S} \\
\mathrm{A} \\
\text { probe }\end{array}$ & $\begin{array}{c}\text { CCCTACGGGCACTGCTCTG } \\
\text { CTGCGTTCTGAGTCAAAGTTG } \\
\text { CTGCCATC }\end{array}$ & $\begin{array}{l}144-162 \\
294-314 \\
203-210\end{array}$ & 171 \\
\hline Cbln 2 & $\begin{array}{c}\text { NM } \\
001012740\end{array}$ & $\begin{array}{c}\mathrm{S} \\
\mathrm{A} \\
\text { probe }\end{array}$ & $\begin{array}{c}\text { TGGCCTTCTCCGCTACTC } \\
\text { CGAGGCAAGGTCAAAGTGGT } \\
\text { TGAGCAAC }\end{array}$ & $\begin{array}{l}457-474 \\
556-575 \\
502-509\end{array}$ & 119 \\
\hline Cbln3 & $\begin{array}{c}\text { XM } \\
001056593\end{array}$ & $\begin{array}{c}\mathrm{S} \\
\mathrm{A} \\
\text { probe }\end{array}$ & $\begin{array}{c}\text { ACCATGAACCAGCAGGAGAA } \\
\text { AAAGCCACCGCCCTCATT } \\
\text { TGCGATCT }\end{array}$ & $\begin{array}{l}483-502 \\
551-568 \\
523-531\end{array}$ & 86 \\
\hline Cbln4 & $\begin{array}{c}\text { XM } \\
001053640\end{array}$ & $\begin{array}{c}\mathrm{S} \\
\mathrm{A} \\
\text { probe }\end{array}$ & $\begin{array}{c}\text { GAGCAACAAGACTCGCATCAT } \\
\text { CAAAGACGGATTCCAGTGTG } \\
\text { CTGGTTAA }\end{array}$ & $\begin{array}{l}1859-1879 \\
1919-1938 \\
1896-1903\end{array}$ & 80 \\
\hline
\end{tabular}

Oligonucleotide sequences for sense (S) and antisense (A) primers, and for probes are shown.

data suggest their involvement, among others, in the regulation of neuroendocrine function (for review see 16). Data on the expression of preCER-related genes and CER polypeptides in endocrine glands are scarce. Therefore, present studies aimed to investigate, by means of molecular biology techniques (RT-PCR, QPCR, Western blotting) their expression in classic endocrine glands of the rat.

\section{Materials and methods}

Studies were performed on intact, adult rats of Wistar strain (130-140 g body weight). Animals were maintained under standardized conditions of light $(14: 10 \mathrm{~h}$ light-dark cycle, illumination onset at 06.00 a.m.), at $23 \pm 2{ }^{\circ} \mathrm{C}$ with free access to standard chow pellets and tap water. The Local Ethics Committee for Animal Studies approved the study protocol.

After decapitation the following organs were promptly removed and subjected to study: hypothalamus, anterior pituitary, thyroid, adrenal, ovary, testis and pancreatic islets (isolated according to 17). As a positive control, fragments of cerebellum and cerebral cortex were applied.

Conventional RT-PCR and QPCR. Methods applied were described earlier (18-23). Briefly, from fragments of studied organs, total RNA was extracted by a method using TRI reagent (Sigma) and purified on columns (RNeasy Mini Kit, Qiagen)(20,22,24,25). Contaminating DNA was eliminated by DNase-I treatment (RNase-Free DNase Set; Promega, Madison, WI), and the amount of total RNA was determined by measuring the optical density at $260 \mathrm{~nm}$. Purity was estimated by $260 / 280 \mathrm{~nm}$ absorption ratio, which was consistently higher than 1.8 . The quality of the obtained product was evaluated using electrophoresis in $1 \%$ agarose gel with ethidium bromide. RT was performed using AMV reverse transcriptase (Promega) with Oligo dT (PE Biosystems, Warrington, UK) as primers. Reaction was performed at $42^{\circ} \mathrm{C}$ for $60 \mathrm{~min}$ (thermocycler UNO II, Biometra). Primers for studies on expression of the precerebellin gene (Table I) and reference genes (Table II) were purchased from the Laboratory of DNA Sequencing and Oligonucleotide Synthesis, Institute of Biochemistry and Biophysics, Polish Academy of Sciences, Warsaw. For all tested genes 34 cycles of the following sequences were applied: denaturation $94^{\circ} \mathrm{C}, 30 \mathrm{sec}$; annealing $58^{\circ} \mathrm{C}, 60 \mathrm{sec}$; extension $68^{\circ} \mathrm{C}, 60 \mathrm{sec}$. In control reactions, water (instead of cDNA) and omission of reverse transcriptase (-RT) were used. Reaction products were separated on ethidium bromide containing $2 \%$ agarose gel and photographed in a transilluminator.

QPCR was performed in a lightcycler 2.0 instrument (Roche) with software version 4.0. Two methods were applied, the SYBR green and TaqMan based detections (probes are shown in Tables I and II). In the SYBR green method the obtained products were characterised by their melting point (precision $0.1^{\circ} \mathrm{C} / \mathrm{sec}$ ). Data were normalized in relation to expression of reference genes. To select the most stable reference gene, by means of GeNorm software we evaluated expression profiles of six different reference genes.

Western blotting. The Western blotting method was used to identify Cbln1 protein in studied organs. Samples were homogenized in RIPA buffer for mammalian cell lysis and centrifuged at $600 \mathrm{x}$ g for $30 \mathrm{~min}$ at $4^{\circ} \mathrm{C}$ to remove cell debris. Protein concentrations were determined by the Bradford method. Subsequently, proteins were separated by gel electrophoresis (Mini-PROTEAN 3, Biorad). Samples of $25 \mu \mathrm{g}$ of protein were loaded into each lane, separated in a $16 \%$ sodium dodecyl sulphate (SDS)-polyacrylamide electrophoretic gel (PAGE), and transferred onto a PVDF membrane (Millipore Co., Bedford, MA, USA). The transferred proteins were stained with Ponceau S. Nonspecific binding was blocked by immersing the membrane in 


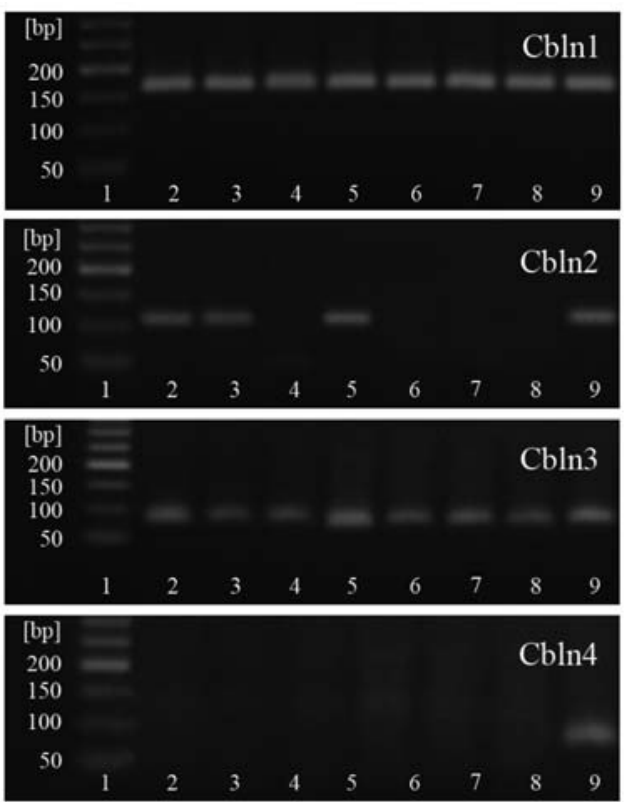

Figure 1. Expression of precerebellin 1-4 (Cbln1-4) genes in endocrine glands of the adult rat. PCR products visualized by gel electrophoresis and stained with ethidium bromide. Amplification of RNA by RT-PCR with selective primer yielded RT-PCR products of expected size (Table I). Lane: 1 , DNA ladder; 2, hypothalamus; 3, anterior pituitary; 4, thyroid; 5, adrenal cortex; 6, testis; 7, ovary; 8 , pancreatic islets; 9 , positive control for Cbln1 and Cbln 3 - cerebellum, for Cbln2 and Cbln 4 cerebral cortex.

5\% BSA at $4^{\circ} \mathrm{C}$ overnight. Membrane was then incubated with primary antibody (anti-Cbln 1 antibody, ProSci Incorporated, San Diego, CA), at a 1:5000 dilution for $1 \mathrm{~h}$ at $37^{\circ} \mathrm{C}$. After washing with TBST (10 mmol/1 TRIS, $\mathrm{pH} 8.0$, $150 \mathrm{mmol} / 1 \mathrm{NaCl}, 0.05 \%$ Tween-20) for $3 \times 10 \mathrm{~min}$, the membranes were further incubated with horseradish peroxidase-conjugated anti-rabbit IgG (Sigma, St. Louis, MO, USA) at a 1: 25,000 dilution for $1 \mathrm{~h}$ at room temperature. The membranes were washed 4 times for 15 min with TBST and the target protein was detected by ECL Advance Western Blotting Detection Kit (Amersham). The chemiluminescence signal was transferred on CL-X Posure Film (Pierce Biotechnology) and the developed film was scanned densitometrically. For data normalization, after striping procedure, GAPDH protein was detected on the same mebranes.

Bioinformatic tools. Two bioinformatic methods were used to predict transmembrane topology of Cbln1. The first one used the HMMTOP transmembrane topology prediction server, which predicts the localization of helical transmembrane segments and the topology of transmembrane proteins (26). This method is operating on the basis of Hidden Markov Model. The second method used the topology predictor SPLIT 4.0, which predicts the sequence location of transmembrane helices by performing an automatic selection of optimal amino acid attribute and corresponding preference functions (27). This program also allows for predicting orientation of an integral protein of the cell membrane.

Statistics. Data are expressed as means \pm SEM and statistical comparison was performed using the unpaired Student's t-test.

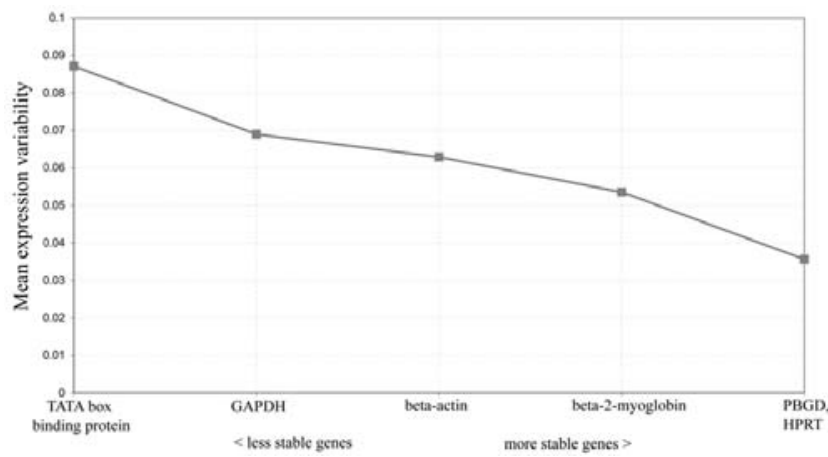

Figure 2. GeNorm Program evaluation of expression stability of reference (housekeeping) genes in endocrine glands of the rat. GAPDH, glyceraldehyde 3-phosphate dehydrogenase; PBGD, porphobilinogen deaminase; HPRT, hypoxanthine-guanine phosphoribosyltransferase.

\section{Results}

By means of conventional RT-PCR method, Cbln 1 and Cbln3 mRNAs were found to be present in all endocrine glands tested; the hypothalamus, anterior pituitary, thyroid, adrenal cortex, testis, ovary and pancreatic islets (Fig. 1). Furthermore, expression of Cbln2 gene was demonstrated only in the hypothalamus, anterior pituitary and adrenal cortex and in the cerebral cortex, which was studied as a positive control organ. On the contrary, expression of Cbln4 gene was found only in cerebral cortex. All amplified products were of expected size and no product was found in RT control assays (data not shown). In the following steps, expression of studied genes was evaluated by means of QPCR.

To select the appropriate housekeeping genes for normalization of quantitative PCR data, expression of the following genes was evaluated in endocrine glands, TATA Box-Binding Protein, GAPDH (glyceraldehyde 3-phosphate dehydrogenase), $\beta$-actin, $\beta 2$ myoglobin, PBGD (porphobilinogen deaminase) and HPRT (hypoxanthine-guanine phosphoribosyltransferase). Stability was evaluated using the GeNorm program (Fig. 2). Of studied genes, the most stable were HPRT and PBGD, and the former was chosen as a reference gene. As seen in Fig. 3, the highest expression of studied Cbln genes was found in positive control organs; Cbln 1 and Cbln 3 in cerebellum and Cbln 2 and Cbln 4 in cerebral cortex. The highest expression of Cbln1 gene was demonstrated in the hypothalamus and pancreatic islets, a somewhat lower one in the anterior pituitary and thyroid, while the lowest expression was demonstrated in the adrenal cortex, testis and ovary. In general, Cbln3 gene exhibited a similar pattern of expression, with the highest level in the pancreatic islets and a somewhat lower one in the hypothalamus. Cbln 2 gene expression was high in the hypothalamus, lower in the anterior pituitary and very low in the adrenal cortex. Again, Cbln4 was not expressed in studied glands.

At the protein level, the highest expression of Cbln 1 was found in the cerebellum, a somewhat lower one in the pancreatic islets, hypothalamus, anterior pituitary and thyroid and low expression was found in the testis, ovary and adrenal cortex (Fig. 4). In general, the obtained pattern of Cbln1 protein expression was similar to that of Cbln1 mRNA. 
Table II. QPCR analysis of reference gene mRNAs.

\begin{tabular}{|c|c|c|c|c|c|}
\hline cDNA & $\begin{array}{c}\text { Genbank } \\
\text { accession no. }\end{array}$ & Primers & Primer sequence (5'-3') & Position & $\begin{array}{c}\text { PCR } \\
\text { product size (bp) }\end{array}$ \\
\hline TATA & NM & $\mathrm{S}$ & АТССТTCACCAATGACTCСТАTG & $618-640$ & 190 \\
\hline binding box & 001004198 & A & ATGATGACTGCAGCAAACC & $789-807$ & \\
\hline \multirow[t]{2}{*}{ GAPDH } & $\mathrm{XM}$ & $\mathrm{S}$ & CCACAGTCCATGCCATCACT & $33-52$ & \multirow[t]{2}{*}{106} \\
\hline & 001073242 & A & TGGTAACCAGGTGTCCGATA & $119-138$ & \\
\hline \multirow[t]{2}{*}{ B-actin } & \multirow[t]{2}{*}{ NM 031144} & $\mathrm{~S}$ & TGAACACGGCATTGTAACCA & 294-313 & \multirow[t]{2}{*}{300} \\
\hline & & A & AGCGCGTAACCCTCATAGAT & $574-593$ & \\
\hline B-2 & \multirow[t]{2}{*}{ NM 012512} & $\mathrm{~S}$ & ACCGAGACCGATGTATATGC & 284-303 & \multirow[t]{2}{*}{137} \\
\hline myoglobin & & A & ACCGGATCTGGAGTTAAACTG & $400-420$ & \\
\hline \multirow[t]{2}{*}{ PBGD } & \multirow[t]{2}{*}{ NM 013168} & $\mathrm{~S}$ & GAAAGACCCTGGAAACCTTG & $397-416$ & \multirow[t]{2}{*}{148} \\
\hline & & A & TGCTCATCCAGCTTCCGTA & $526-544$ & \\
\hline \multirow[t]{2}{*}{ HPRT } & \multirow[t]{2}{*}{ NM 012583} & $\mathrm{~S}$ & CAGTCAACGGGGGACATAAAAG & $391-412$ & \multirow[t]{2}{*}{146} \\
\hline & & A & ATTTTGGGGCTGTACTGCTTGA & $515-536$ & \\
\hline
\end{tabular}

Oligonucleotide sequences for sense (S) and antisense (A) primers, and for probes are shown. GAPDH, glyceraldehyde 3-phosphate dehydrogenase; PBGD, porphobilinogen deaminase; HPRT, hypoxanthine-guanine phosphoribosyltransferase; HPRT (hypoxanthineguanine phosphoribosyl transferase).

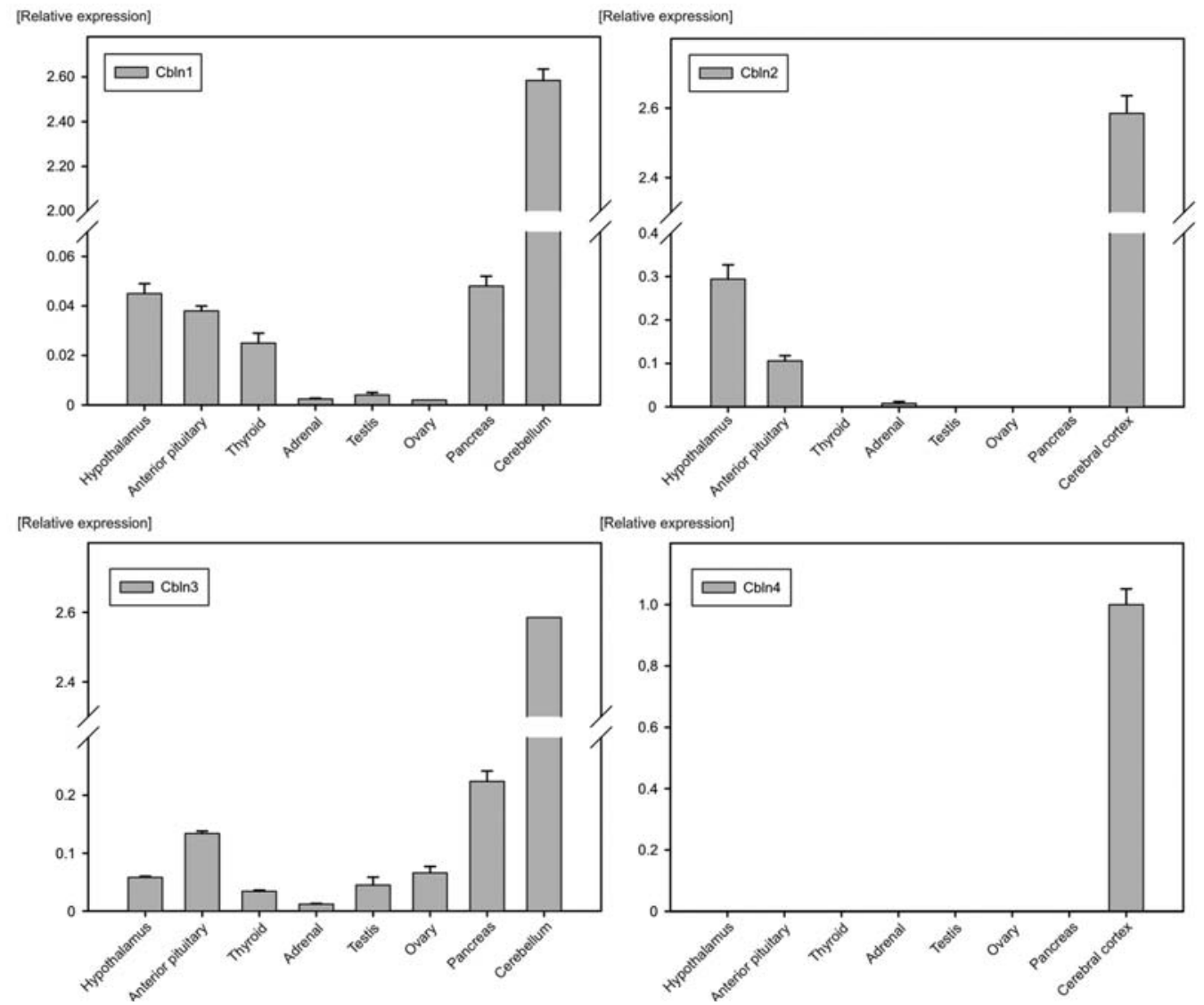

Figure 3. QPCR analyses of Cbln1-4 gene expression in endocrine glands of the adult rat. 1, Hypothalamus; 2, anterior pituitary; 3, thyroid; 4, adrenal cortex; 5, testis; 6, ovary; 7, pancreatic islets; 8 , positive control for Cbln 1 and 3 - cerebellum, for Cbln 2 and 4 cerebral cortex. Bars present a mean of 4 independent assays and \pm SEM is shown. HPRT gene expression was used as reference to normalize data.

Further experiments were performed aimed at clarifying the association of Cbln1 with cell membrane. Proteins were extracted from fragments of cerebellum either with RIPA or
TRIS buffer. RIPA buffer enables extraction of integral and peripheral membrane proteins while TRIS buffer preferentially extracts peripheral proteins. Western blotting identified 


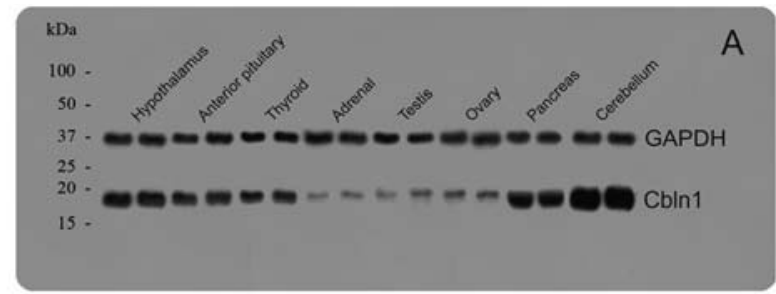

[pixel intensity]

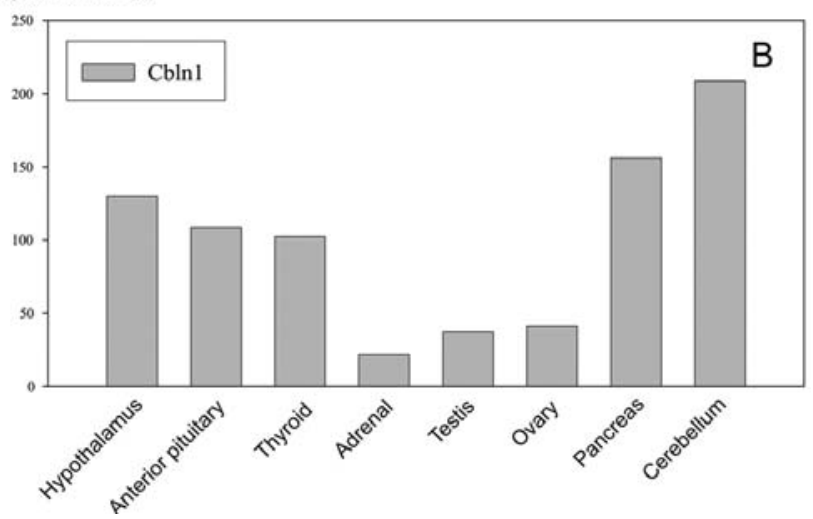

Figure 4. Semiquantitative evaluation of Cbln 1 protein expression in endocrine glands of the rat. (A) Western blotting, chemiluminescence signals of Cbln1 and GAPDH on developed film; (B) densitometrically evaluated relative (in relation to GAPDH) intensity of Cbln 1 protein expression. Studied organs are shown: hypothalamus, anterior pituitary, thyroid, adrenal cortex, testis, ovary, pancreatic islets and cerebellum. Bars present means of 2 experiments.

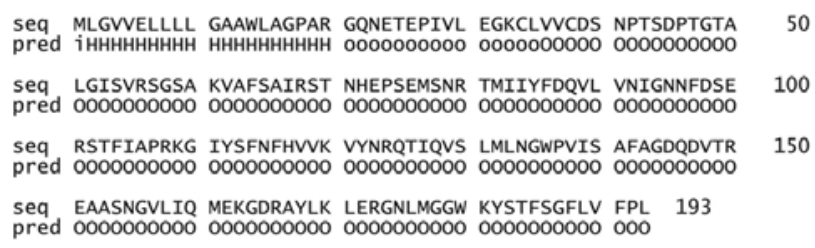

Figure 6. Bioinformatic analysis of the localization of helical transmembrane segments and the topology of transmembrane Cbln1 protein. Data obtained by means of HMMTOP transmembrane topology prediction server; seq, amino acid sequence; pred, predicted localisation; i, intracellular region; $\mathrm{H}$, alpha-helix of transmembrane region; $\mathrm{O}$, extracellular region.

Cbln1, as described above. Intensity of Cbln1 strip was higher in RIPA than in TRIS protein extracts (Fig. 5).

Results of both bioinformatic methods predicting transmembrane topology of Cbln1 [HMMTOP (Fig. 6) and SPLIT 4.0 (Fig. 7)] suggested transmembrane localisation of Cbln1, with transmembrane domain sequence responsible for the formation of $\alpha$-helix.

\section{Discussion}

Performed at mRNA and protein levels, the systemic studies on Cbln have revealed their characteristic pattern of expression in the endocrine glands of the rat. This pattern has differed notably from that seen in the CNS and has suggested an important, not yet fully recognised role of Cbln and related peptides in the functioning of the endocrine system.

At present four precerebellins are recognised, designated as Cbln1-4, and their genes are located at different
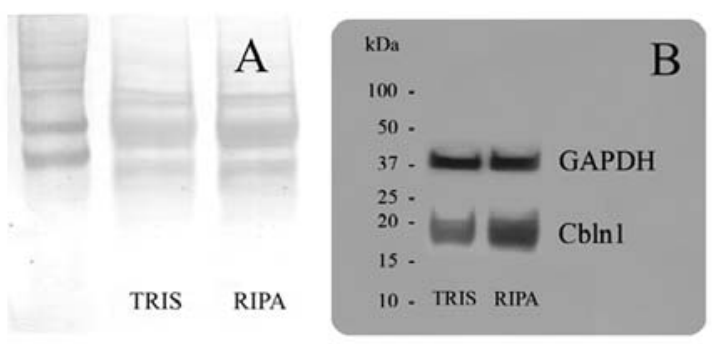

[pixel intensity]

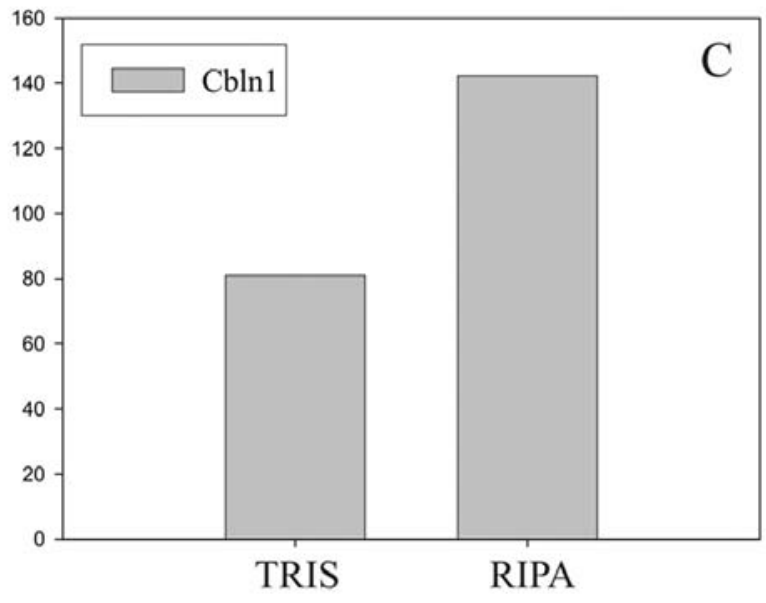

Figure 5. Semiquantitative evaluation of Cbln1 protein expression in extracts from cerebellum of the adult rat. (A) Western blotting; proteins stained with Ponceau S; (B) chemiluminescence signals of Cbln 1 and GAPDH on developed film; (C) densitometrically evaluated relative (in relation to GAPDH) intensity of Cbln1 protein expression. TRIS, proteins extracted with TRIS buffer; RIPA, proteins extracted with RIPA buffer.

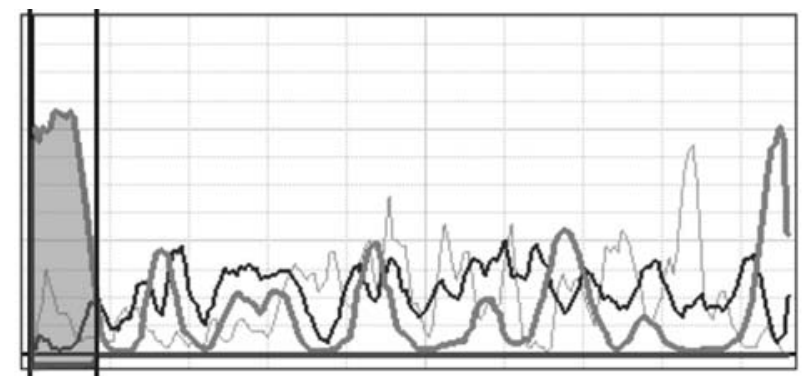

Figure 7. Result of bioinformatic analysis of Cbln1 amino acid sequence by topology predictor SPLIT 4.0 program. Thick gray line, preference for $\alpha$-helix; black line, preference for $\beta$ sheet; gray area shows localisation of $\alpha$-helix transmembrane region; vertical continuous gray lines of background, 100 aa length; vertical interrupted gray lines of background, 20 aa length.

chromosomes. Recent findings suggest that from an evolutionary point of view Cbln 4 may be the prototype of the Cbln subfamily genes and peptides. All Cbln are expressed in CNS and at least 3 of them are secreted $(6,8,9,13,15)$.

The earliest studies on the localization of Cbln-related peptides were performed by means of RIA and HPCL. They revealed the presence of RIA-assayable CER and CER or desCER polypeptide (by means of HPLC) in various regions of the brain, with the highest concentration in the cerebellum 
(1-3,28). In relation to the CNS, concentrations of CER are significantly lower in the heart, kidney, stomach, alimentary tract and spleen $(2,5)$. Of particular note is the presence of relatively high CER concentrations in normal human adrenal gland and adrenal tumours, originating either from the cortex or medulla (29).

Thorough molecular biology-based studies (RT-PCR, Northern blot and in situ hybridisation) have demonstrated expression of Cbln $1 \mathrm{mRNA}$ in granular cells and deep nuclei in the cerebellum and certain thalamic nuclei. The expression of Cbln 2 mRNA is widespread in the CNS, while the expression of Cbln3 and Cbln 4 mRNAs are restricted to cerebellar granular cells and certain thalamic nuclei $(7,15)$. Our studies have confirmed expression of Cbln 1 and 3 in the cerebellum and Cbln 2 and 4 in the rat cerebral cortex.

In our studies, expression of Cbln1-3 at mRNA level has been found to be present in the rat hypothalamus, anterior pituitary and adrenal glands. Expression of CER-like peptide, CER and CER mRNA in the hypothalamus was reported earlier $(2,29)$, while recently Segal et al (30) also demonstrated expression of Cbln1 mRNA in the ventromedial hypothalamic nucleus. Furthermore, we have also demonstrated hypothalamic expression of Cbln1 at the protein level. A similar pattern of Cbln related gene expression has been found in the anterior pituitary gland and adrenal cortex. As revealed in these studies, in the rat anterior pituitary gland Cbln1-3 are expressed at mRNA levels and Cbln1 also at protein level. In relation to this, Satoh et al (29) previously reported the presence of CER-immunoreactive substances in the human pituitary gland.

The adrenal gland is one of the organs in which Cbln are highly expressed. By means of Northern and Southern blotting, CER expression was demonstrated in the rat adrenal gland by Wada and Ohtani (5). Furthermore, in normal human adrenal glands and in adrenal tumours, the presence of immunoreactive CER and Cbln1 mRNA were demonstrated by Satoh et al (29). In their ICH studies, CER-like immunoreactivity was demonstrated primarily in the adrenal medulla. However, Cbln1 mRNA was not detected in normal human adrenal glands using a Northern blot analysis or by RT-PCR $(4,15,29)$. Expression of Cbln1-3 in rat adrenal glands had been reported earlier by our group (20) and those earlier observations have been extended in the present studies by demonstration of Cbln 1 protein expression in the gland. These data are in contrast with NCBI presented data (NM_080617), in which the expression of Cbln4 in the human adrenal gland is listed in second place (after nerve tissue).

In the remaining studied endocrine glands, only expression of Cbln 1 and Cbln3 mRNAs and Cbln 1 protein have been found. Such a pattern of precerebellin gene and protein expression has been found in the thyroid, testis, ovary and pancreatic islets. In available literature scarce data exist on expression of Cbln in these organs. Only recently Ikeda et al (31) studied expression of the Cbln1 gene as a marker of early testicular differentiation in the mouse. They found that the Cbln1 gene is expressed in interstitial cells of the male but not female gonads.

A semiquantitative approach has revealed the highest expression of the Cbln1 gene in hypothalamus and pancreatic islets, a somewhat lower one in the anterior pituitary and thyroid, while the lowest was found in the adrenal cortex, testis and ovary. The Cbln3 gene exhibited a similar pattern of expression. Cbln2 gene expression, however, was high in the hypothalamus, lower in the anterior pituitary and very low in the adrenal cortex.

In general, in our experiments the degree of Cbln 1 expression at the protein level has paralleled the degree of Cbln 1 mRNA expression. These findings suggest that in studied glands Cbln 1 expression (from transcription to translation) is primarily regulated at the transcription level.

After CER identification, it appeared that the polypeptide was derived from the Cbln1, a member of the C1q family of peptides $(4,5)$. Cbln 1 is a transmembrane protein with putative transmembrane domains comprising amino acids 29-47, which are able to form an $\alpha$-helix. Results of our bioinformatics searches have confirmed this suggestion. In membrane anchored Cbln1, the CER-like sequence is localised extracellularly and liberation of CER from Cbln1 requires proteolytic cleavage. Since neither an N-terminal cleavable signal peptide nor dibasic pair specific endopeptidase directly precedes or follows the cerebellin-like sequence, CER is not liberated from Cbln1 by the classical dibasic amino acid proteolytic-cleavage mechanism seen in various neuropeptide precursors. This mechanism of CER liberation from Cbln1 resembles mechanism of TNF $\alpha$ maturation $(13,32,33)$.

As proved by experimental data, liberated CER exerts various biological activities. In this regard initially it was suggested that the N-terminal truncated version of CER (desSer1-CER) is an apparent metabolite of CER $(1-3,28)$. However, a growing body of evidence clearly demonstrates regulatory effects of CER and desCER in the functioning of various organs, in particular of the endocrine system $(20,34$ 37). In relation to these data it should be emphasised that CER-like immunoreactivity could not be demonstrated in the blood (29). This finding suggests that CER, and probably desCER, regulates biological activity of various cells in a paracrine manner.

However, not only Cbln derived polypeptides are biologically active compounds. Previously, Iijima et al (14) in mammalian heterologus cells demonstrated secretion of entire Cbln molecules, as N-linked glycoproteins (Cbln1, Cbln2, Cbln4) into the extracellular space where they formed with each other in vitro not only homomeric but also heteromeric complexes $(7,33)$. It has been suggested that the complexes regulate synapse development and synaptic plasticity, especially in the cerebellum (9). Furthermore, it may by hypothetised that formation of heteromeric Cbln complexes may be specific for particular organs or cells and/or specific for the regulation of a particular biological function. Until now, no Cbln-related receptor has been identified. However, the formation of Cbln complexes suggests that they might interact with a membrane receptor(s) and activate intracellular transduction cascades (8).

Collectively, the obtained results have shown the expression of Cbln1-3 mRNAs and Cbln1 protein in the classic endocrine glands of the adult rat. These findings suggest possible physiological roles of Cbln-related peptides not only in the cerebellum, but also in the endocrine system. However, their specific role as modulators of the endocrine system requires further investigation. 


\section{Acknowledgements}

This study was supported by a grant from the State Committee for Scientific Research (0220/P01/2006/30). Some experiments were performed in the Department of Anatomy and Physiology, University of Padova, Italy during the Short Term Fellowship granted by the Federation of European Biochemical Societies (FEBS). This study was in partial fulfillment of a Ph.D. thesis requirement for M. Rucinski, of the University of Medical Sciences, Poznan, Poland.

\section{References}

1. Slemmon JR, Blacher R, Danho W, Hempstead JL and Morgan JI: Isolation and sequencing of two cerebellum-specific peptides. Proc Natl Acad Sci USA 81: 6866-6870, 1984.

2. Burnet PWJ, Bretherton-Watt D, Ghatei MA and Bloom SR: Cerebellin-like peptide: Tissue distribution in rat and guinea-pig and its release from rat cerebellum, hypothalamus and cerebellar synaptosomes in vitro. Neuroscience 25: 605-612, 1988.

3. Yiangou Y, Burnet P, Nikou G, Chrysanthou BJ and Bloom SR: Purification and characterisation of cerebellins from human and porcine cerebellum. J Neurochem 53: 886-889, 1989.

4. Urade Y, Oberdick J, Molinar-Rode R and Morgan JI: Precerebellin is a cerebellum-specific protein with similarity to the globular domain of complement C1q B chain. Proc Natl Acad Sci USA 88: 1069-1073, 1991.

5. Wada $\mathrm{CH}$ and Ohtani $\mathrm{H}$ : Molecular cloning of rat cerebellinlike protein cDNA witch encodes a novel membrane associated glycoprotein. Mol Brain Res 9: 71-77, 1991.

6. Kavety B, Jenkins NA, Fletcher CF, Copeland NG and Morgan JI: Genomic structure and mapping of precerebellin and a precerebellinrelated gene. Brain Res Mol Brain Res 27: 152-156, 1994.

7. Pang Z, Zuo J and Morgan JI: Cbln3, a novel member of the precerebellin family that binds specifically to Cbln 1 . J Neuroscience 20: 6333-6339, 2000.

8. Dicou E: Biologically active, non membrane-anchored precursors: an overview. FEBS J 275: 1960-1975, 2008.

9. Yuzaki M: Cbln and C1q family proteins: new transneuronal cytokines. Cell Mol Life Sci 65: 1698-1705, 2008.

10. Muragaki Y, Shiota C, Inoue M, Ooshima A, Olsen BR and Ninomiya Y: Alpha I(VIII)-collagen gene transcripts encode a short-chain collagen polypeptide and are expressed by various epithelial, endothelial and mesenchymal cells in newborn mouse tissues. Eur J Biochem 207: 895-902, 1992.

11. Elima K, Eerola I, Rosati R, Metsaranta M, Garofalo S, Perala M, De Crombrugghe B and Vuorio E: The mouse collagen X gene: complete nucleotide sequence, exon structure and expression pattern. Biochem J 289: 247-253, 1993.

12. Petry F, Reid KB and Loos M: Molecular cloning and characterization the complementary DNA coding for the Bchain of murine C1q. FEBS Lett 258: 89-93, 1989.

13. Petry F, Reid KB and Loos M: Isolation, sequence analysis and characterization of cDNA clones coding for the $\mathrm{C}$ chain of mouse C1q. Sequence similarity of complement subcomponent C1q, collagen type VIII and type X and precerebellin. Eur J Biochem 209: 129-134, 1992.

14. Iijima T, Miura E, Matsuda K, Kamekawa Y, Watanabe M and Yuzaki M: Characterization of a transneuronal cytokine family Cbln regulation of secretion by heteromeric assembly. Eur J Neurosci 25: 1049-1057, 2007

15. Miura E, Iijima T, Yuzaki M and Watanabe M: Distinct expression of Cbln family mRNAs in developing and adult mouse brains. Eur J Neurosci 24: 750-760, 2006.

16. Takachashi K, Totsune K and Murakami O: Adrenocortical peptides: autocrine or paracrine regulators for the steroid hormone secretion or the cell proliferation? Exp Clin Endocrinol Diabetes 110: 373-380, 2002.

17. Lacy PE and Kostianovsky M: Method for the isolation of intact islets of Langerhans from the rat pancreas. Diabetes 16: 35-39, 1967.

18. Albertin G, Carraro G, Parnigoto PP, Ziolkowska A, Malendowicz LK and Nussdorfer GG: Human skin keratinocytes and fibroblasts express adrenomedullin and its receptors, and adrenomedullin enhances their growth in vitro by stimulating proliferation and inhibiting apoptosis. Int J Mol Med 11: 635-639, 2003.
19. Tortorella C, Macchi C, Spinazzi R, Malendowicz LK, Trejter M and Nussdorfer GG: Ghrelin, an endogenous ligand for the growth hormone-secretagogue receptor, is expressed in the human adrenal cortex. Int J Mol Med 12: 213-217, 2003.

20. Rucinski M, Albertin G, Spinazzi R, Ziolkowska A, Nussdorfer GG and Malendowicz LK: Cerebellin in the rat adrenal gland: gene expression and effects of CER and [des-Ser ${ }^{1}$ CER on the secretion and growth of cultured adrenocortical cells. Int J Mol Med 15: 411-415, 2005.

21. Rucinski M, Ziolkowska A, Neri G, Trejter M, Zemleduch T, Tyczewska M, Nussdorfer, GG and Malendowicz LK: Expression of neuromedins $\mathrm{S}$ and $\mathrm{U}$ and their receptors in the hypothalamus and endocrine glands of the rat. Int J Mol Med 20: 255-259, 2007.

22. Rucinski M, Ziolkowska A, Tyczewska M, Szyszka M and Malendowicz LK: Neuromedin U directly stimulates growth of cultured rat calvarial osteoblast-like acting via the NMU receptor isoform. Int J Mol Med 22: 363-368, 2008.

23. Ziolkowska A, Rucinski M, Tortorella C, Tyczewska M, Nussdorfer GG and Malendowicz LK: Cultured rat calvarial osteoblast-like cells are provided with orexin type 1 receptors. Int J Mol Med 20: 779-782, 2007

24. Rucinski M, Ziolkowska A, Hochol A, Pucher A, Macchi C, Belloni AS, Nussdorfer GG and Malendowicz LK: Estradiol and resveratrol stimulating effect on osteocalcin, but not osteonectin and collagen- $1 \alpha$ gene expression in primary culture of rat calvarial osteoblast-like cells. Int J Mol Med 18: 565-570, 2006.

25. Albertin G, Rucinski M, Carraro G, Forneris M, Andreis P Malendowicz LK and Nussdorfer GG: Adrenomedullin and vascular endothelium growth factor genes are overexpressed in the regenerating rat adrenal cortex, and AM and VEGF reciprocally enhance their mRNA expression in cultured rat adrenocortical cells. Int J Mol Med 16: 431-435, 2005.

26. Tusnády GE and Simon I: The HMMTOP transmembrane topology prediction server. Bioinformatics 17: 849-850, 2001.

27. Juretic D, Zoranic L and Zucic D: Basic charge clusters and predictions of membrane protein topology. J Chem Inf Comput Sci 42: 620-632, 2002.

28. Slemmon JR, Danho W, Hempstead JL and Morgan JI: Cerebellin: a quantifiable marker for Purkinje cell maturation. Proc Natl Acad Sci USA 82: 7145-7148, 1985.

29. Satoh F, Takahashi K, Murakami O, Totsune K, Ohneda M, Mizuno Y, Sone M, Miura Y, Takase S, Hayashi Y, Sasano H and Mouri T: Cerebellin and cerebellin mRNA in the human brain, adrenal glands and the tumour tissues of adrenal tumour, ganglioneuroblastoma and neuroblastoma. J Endocrinol 154: 27-34, 1997.

30. Segal JP, Stallings NR, Lee CE, Zhao L, Socci N, Viale A, Harris TM, Soares MB, Childs G, Elmquist JK, Parker KL and Friedman JM: Use of laser-capture microdissection for the identification of marker genes for the ventromedial hypothalamic nucleus. J Neurosci 25: 4181-4188, 2005.

31. Ikeda Y, Tanaka H and Esaki M: Effects of gestational diethylstilbestrol treatment on male and female gonads during early embryonic development. Endocrinology 149: 3970-3979, 2008.

32. Patel IR, Attur MG, Patel RN, Stuchin SA, Abagyan RA, Abramson SB and Amin AR: TNF-alpha convertase enzyme from human arthritis-affected cartilage: isolation of cDNA by differential display, expression of the active enzyme, and regulation of TNF-alpha. J Immunol 160: 4570-4579, 1998.

33. Bao D, Pang Z and Morgan JI: The structure and proteolytic processing of Cbln1 complexes. J Neurochem 95: 618-269, 2005.

34. Mazzocchi G, Andreis PG, De Caro R, Aragona F, Gottardo L and Nussdorfer GG: Cerebellin enhances in vitro secretory activity of human adrenal gland. J Clin Endocrinol Metab 84: 632-635, 1999

35. Albertin G, Malendowicz LK, Macchi C, Markowska A and Nussdorfer GG: Cerebellin stimulates the secretory activity of the rat adrenal gland: in vitro and in vivo studies. Neuropeptides 34: 7-11, 2000.

36. Malendowicz LK, Hochol A, De Caro R, Trejter M, Markowska A, Nussdorfer GG and Nowak M: Effect of cerebellin on the pituitary-adrenocortical function in adult rats and the proliferative activity of immature and regenerating rat adrenal cortex. Biomed Res 21: 85-88, 2000.

37. Hochol A, Neri G, Majchrzak M, Ziolkowska A, Nussdorfer GG and Malendowicz LK: Prolonged cerebellin administration inhibits the growth, but enhances steroidogenic capacity of rat adrenal cortex. Endocr Res 27: 11-17, 2001. 